\title{
ニューラルネットワーク分析手法による \\ 都市キャノピー幾何情報の推定に関する研究 \\ ESTIMATION METHOD FOR URBAN CANOPY GEOMETRIC INFORMATION USING NEURAL NETWORK
}

\author{
足 永靖 信*1, 平野洪 賓*2 \\ Yasunobu ASHIE and Kohin HIRANO
}

\begin{abstract}
The geometric information of cities is indispensable in various areas of urban studies. In this paper, authors report the result of creating the meshed geometry data of Tokyo metropolitan from Detailed Digital Information (10m Grid Land Use), National Population Census, and Establishment and Enterprise Census by simple regression, multiple linear regression analysis, and neural network. The neural network showed finest performance among three methods, its estimating accuracy may reach $0.6\left(\mathrm{R}^{2}\right.$, coefficient of determination) in all evaluated items in the case that whole targets are used as training signal. To check the general versatility of neural networks, Maharanobis distance was usd to evaluate the similarity of cities , and it was found that neural network is capable of high presition when the Maharanobis distance is under 15.
\end{abstract}

Keywords: Geographic Information System, Detailed Digital Information, Multiple Linear Regression,

Neural Network, Urban Canopy Geometric Information

GIS, 細密数值情報, 重回帰分析, ニューラルネットワーク, 都市キャノピー幾何情報

\section{1. はじめに}

都市の建築土地利用は都市空間の居住性や安全性に大きく影 響する。これまで都市 GIS を用いて都市形態に関する様々な研

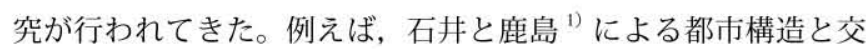
通エネルギー消費量, 宮崎と森山 ${ }^{2)}$ による地震火災規模と市 街地特性, 伊藤ら ${ }^{3)}$ による都市の空間構成要素と犯罪, の関 連研究が見られる。また, 都市気候分野においては, 建物の形 状やその地域分布が都市スケールの気候・気象に密接に関係し ていると考えられている。地表面に接する都市キャノピー層で は大気との間で運動量・顕熱・潜熱の交換が盛んになされてい て, 建物による抗力, 蓄・・放熱, 日陰効果による運動量・熱輸 送への影響が無視できない（例えば，神田ら 20084)，足永ら $\left.2007^{5}\right)$ 。都市キャノピーモデルを用いた数值シミュレーション を実施する場合，建物の面積や高さを都市キャノピー層におい て幾何的な情報として集約する必要がある。

しかし, 自治体が管理する建物 GIS データを入手困難なケー スに遭遇することが多く，広域な入力データ整備自体にも膨大 な労力が費やされるため, 都市キャノピーモデルによる数值シ
ミュレーションの準備作業は容易くない。

そこで, 筆者らは一般に入手が容易い細密数值情報及び国勢調 査などより都市キャノピーモデルの入力データベースを簡易に 整備する手法を提案する。都市キャノピーモデルの多くは, 単純 な建物形状及び均一な建物配置を想定しており，建物用途ごと の建築面積率, 建物高さ, 及び建物の平均的な水平幅により幾 何形状が規定される。本論文ではこれらを取りまとめて都市キャ ノピー幾何情報と定義する。そして, 建物 GIS データから都市 キャノピー幾何情報をメッシュごとで正確に算出してから，こ れらを細密数值情報などから簡易に推定する手法として, 単回 帰分析, 重回帰分析及びニューラルネットワークの 3 通りを考え, 予㵋精度の比較を行った。

ニューラルネットワークは人間の脳の仕組みを模倣した情報 処理システムであり，観測データを補間し予測を行う手法の一 つである。都市分野における研究例としては, 上田ら ${ }^{6)}$ の気温 のメッシュ気候值作成, 宮崎と森山 ${ }^{7)}$ の気温分布の推定への応

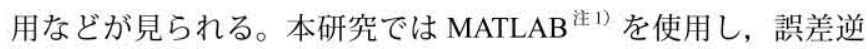

$* 1$ 独立行政法人建築研究所 上席研究員 . 工博

$* 2$ 独立行政法人建築研究所 博士 (工学)
Chief Research Engineer, Building Research Institute, Dr. Eng. Building Research Institute, Dr. Eng. 
伝搬（Backpropagation）法によるニューラルネットワークを適用 し建物用途別に都市キャノピー幾何情報を推定する。

\section{2. トレーニングデータの作成}

\section{2-1. 解析対象}

解析対象は東京都の区部及び多摩地域である。ただし, 多摩地 域の山間部は建物 GIS データが整備されていないため解析対象 から除外した。

\section{2-2. 土地利用分類}

東京都都市計画地理情報システムのデータ（以降, 東京都 GIS データと称する）と細密数值情報の分類が異なるため, 土地利用 分類を 8 項目, 建物用途 3 項目とし, 表 1 の対応関係を定義した。

\section{2-3. 作成年度について}

東京都 GIS データの作成年は, 区部は 1996 年, 多摩地域は 1997 年である。細密数值情報は 1994 年版を使用している。調査 年度の違いによるデータの変動を抑えるため, 解析対象の 4 次 メッシュ（メッシュ面積が約 25ha）の内, 空地・緑地の面積が 24ha 以下, 居住用地, 商工用地, 工業用地, 及び農業用地につ いて東京都 GIS データと細密数值情報の土地利用面積の差が 5 ha 以下となる計 4253 メッシュを抽出した。更に上記メッシュの内, 平成 7 年国勢調査及び平成 8 年事業所・企業統計調査のデータが 整備されているのは 3903 メッシュであったため, 以降の推定は これらを用いる。

\section{2-4. 土地利用面積率の推定}

表 1 の対応関係に基づき, 東京都 GIS データと細密数值情報 の土地利用を 4 次メッシュごとに集計し, 土地利用面積率として 整理した。細密数值情報の 15 分類を独立変数として, 土地利用 項目の 4 分類（居住用地, 商公用地, 工業用地, 道路用地）を従 属変数とする。なお, 各メッシュにおいて, ある土地利用が占め るメッシュ面積の割合をその土地利用の面積率とする。

推定方法として, 単回帰分析, 重回帰分析及びニューラルネッ トワーク (4 層構造, 䛊差逆伝搬階層法) 注2) を考え, 計算結果 を表 2 に一覧する。ここで単回帰分析の補正前, 補正後とは道路 用地の他用途への読み替え影響の補正の有無を示す (2-5 参照)。 土地利用面積率の推定精度はニューラルネットワークが最も高 く, 次いで重回帰分析, 単回帰分析 (補正後) となった。これら はすべての土地利用分類において決定係数が 0.7 以上となり，い ずれも十分な予測精度を有しており有効な推定方法と言える。

\section{2-5. 道路用地について}

道路用地の面積率は東京都 GIS データと比較して, 細密数值 情報が過小評価する傾向がある。細密数值情報の道路用地は幅
員 $4 \mathrm{~m}$ 以上の道路を対象としており, 幅員 $4 \mathrm{~m}$ 末満の細街路の面 積が集計に反映されない。また，10m メッシュ内の道路の面積規

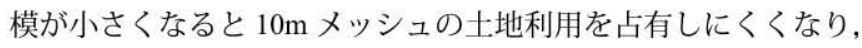
他の土地利用に読み替えられることがある。したがって, 細密数 值情報は細街路を見落とす可能性が高い。そこで，居住用地，商 公用地, 工業用地において読み替えられている道路面積を東京都 GIS データから地域全体で集計し，土地利用ごとに各メッシュで 道路の読み替え分を差し引き，その分を道路用地に加算した。そ の結果, 道路用地の単回帰式の勾配は 0.82 から 1.01 に改善した。 表 3 は重回帰分析の標準偏回帰係数の一覧である。道路用地の場

\section{表 1 土地利用分類の対応関係}

\begin{tabular}{|c|c|c|c|}
\hline \multicolumn{2}{|c|}{ 本研究の分類 } & \multirow{2}{*}{$\begin{array}{c}\text { 東京都 GIS データの } \\
\text { 土地利用分類 } \\
\end{array}$} & \multirow{2}{*}{$\begin{array}{c}\text { 細密数值情報の } \\
\text { 土地利用分類 }\end{array}$} \\
\hline 土地利用 & 建物用途 & & \\
\hline 居住用地 & 住居系 & $\begin{array}{l}\text { 専用独立住宅地 } \\
\text { 集合住宅 }\end{array}$ & $\begin{array}{l}\text { 一般低層住宅地 } \\
\text { 密集低層住宅地 } \\
\text { 中高層住宅地 }\end{array}$ \\
\hline 商公用地 & 商公系 & $\begin{array}{l}\text { 官公庁施設 } \\
\text { 教育文化施設 } \\
\text { 厚生医療施設 } \\
\text { 供給処理施設 } \\
\text { 鉄道・港湾等 } \\
\text { 自動車車庫等 } \\
\text { 倉庫・流通センター } \\
\text { 事務所建築物 } \\
\text { 専用商業施設等 } \\
\text { 住商併用建物 } \\
\text { 宿泊・遊興施設 } \\
\text { スポーツ興業施設 }\end{array}$ & $\begin{array}{l}\text { その他の公共公益施設 } \\
\text { 商業・業務用地 }\end{array}$ \\
\hline 工業用地 & 工業系 & $\begin{array}{l}\text { 専用工場・作業所 } \\
\text { 住居併用工場・作業所 }\end{array}$ & 工業用地 \\
\hline 空地・緑地 & - & $\begin{array}{l}\text { 屋外利用地・仮設建物 } \\
\text { 公園・運動場等 } \\
\text { 未建築宅地・未利用地等 } \\
\text { 原野 } \\
\text { 森林 }\end{array}$ & $\begin{array}{l}\text { 造成中地 } \\
\text { 空地 } \\
\text { 山林・空地等 } \\
\text { 公園・緑地等 }\end{array}$ \\
\hline 道路用地 & - & 道路 & 道路用地 \\
\hline 農業用地 & - & $\begin{array}{l}\text { 農林漁業施設 } \\
\text { 田 } \\
\text { 畑 } \\
\text { 樹園地 } \\
\text { 採草放牧地 }\end{array}$ & $\begin{array}{l}\text { 田 } \\
\text { 畑・その他の農地 }\end{array}$ \\
\hline 水系 & - & 水面・河川・水路 & 河川・湖沼等 \\
\hline その他 & - & その他 & その他 \\
\hline
\end{tabular}

表 2 細密数值情報を用いた土地利用面積率の推定結果

\begin{tabular}{|c|c|c|c|c|}
\hline \multirow[b]{2}{*}{ 土地利用分類 } & \multicolumn{2}{|c|}{ 単回帰分析 R²[-] } & \multirow{2}{*}{$\begin{array}{c}\text { 重回帰分析 } \\
\mathrm{R}^{2}[-]\end{array}$} & \multirow{2}{*}{$\begin{array}{c}\text { ニューラルネットワーク } \\
\mathrm{R}^{2}[-]\end{array}$} \\
\hline & 補正前"* & 補正後䏠 & & \\
\hline 居住用地 & 0.931 & 0.931 & 0.943 & \begin{tabular}{|c|}
0.974 \\
\end{tabular} \\
\hline 商公用地 & 0.885 & 0.885 & 0.894 & 0.959 \\
\hline 工業用地 & 0.929 & 0.929 & 0.932 & 0.990 \\
\hline 道路用地 & 0.683 & 0.716 & 0.797 & 0.915 \\
\hline
\end{tabular}

表 3 土地利用面積率に関する重回帰分析の標準偏回帰係数

\begin{tabular}{|c|c|c|c|c|c|c|c|c|c|c|c|c|c|c|c|c|}
\hline 土地利用分類 & 切片 & 一般低層| & 密集低層 & 中高層 & 公共公益 & 商業業務 & 工業 & 造成中 & 空地 & 山林空地 & 公園緑地 & 道路 & 田 & 畑農地 & 河川湖沼 & その他 \\
\hline 居住用地 & 0.000 & 0.977 & 0.397 & 0.310 & 0.033 & 0.014 & 0.029 & 0.019 & 0.031 & $\begin{array}{l}0.049 \\
\end{array}$ & 0.020 & 0.106 & -0.003 & 0.078 & 0.001 & 0.017 \\
\hline 商公用地 & 0.000 & -0.024 & -0.017 & -0.022 & 0.693 & 0.565 & -0.002 & 0.004 & -0.010 & -0.049 & 0.033 & 0.027 & -0.001 & -0.036 & -0.037 & $\overline{-0.011}$ \\
\hline 工業用地 & 0.000 & 0.041 & 0.054 & 0.000 & 0.012 & 0.046 & 0.981 & 0.006 & 0.009 & 0.024 & 0.010 & 0.016 & -0.007 & 0.031 & 0.010 & 0.009 \\
\hline
\end{tabular}


合, 道路自身の值は 0.712 と低く, 一般低層 $(0.243)$ など他の土 地利用から面積を補っていることが分かる。

\section{2-6. 都市キャノピー幾何情報の集計}

既報 ${ }^{8)}$ にならい，東京都 GIS データを用いて都市キャノピー 幾何情報を作成する。4 次メッシュ内の土地面積に対する建物 1 階部分の面積の割合を求め, 建物用途ごとの建築面積率 $(0 \sim 1)$ を集計した。建物の階高は建物用途により異なることがわかって いることから ${ }^{9)}$, 本研究では建物階数により建物高さを取り报う。 建物の平均的な水平幅は 1 棟当たりの建築面積の平方根とした。

建物用途は住居系, 商公系, 工業系の 3 つを考え, トレーニン グデータの出力部分は 9 項目となる。

\section{2-7. トレーニングデータの入カ部分}

都市キャノピー幾何情報の推定に必要となる入力は以下の通り である。

まず，土地利用面積率については 2-4 で述べた居住用地，商公 用地, 工業用地の 3 項目とし, ニューラルネットワークによる細 密数值情報からの推定值を用いる。これに加えて, 細密数值情報 の一般低層, 密集低層及び中高層住宅地の面積率（いずれも居住 用地の面積を基準とする）も活用する。

さらに, 平成 7 年国勢調査の夜間人口, 昼間人口, 流人人口, 及び平成 8 年事業所・企業統計調查の第 2 次産業の事業所数, 従 業者数, 第 3 次産業の事業所数, 従業者数, 計 7 項目を追加して いる。トレーニングデータの入力部分は計 13 項目である。

\section{3. 都市キャノピー幾何情報の推定}

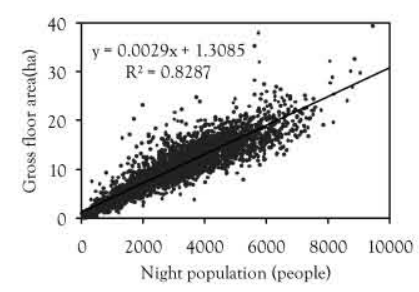

図 1 夜間人口と住居系建物の 延べ床面積の関係

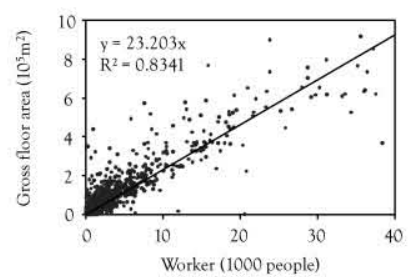

図 3 第 3 次産業從業者数と商 公系建物の延べ床面積の 関係

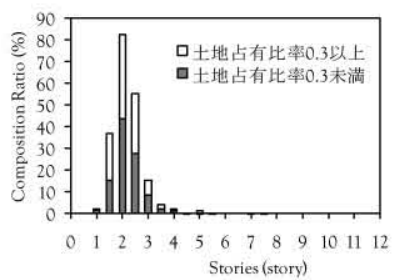

図 5 工業系建物の階数の頻度 分布

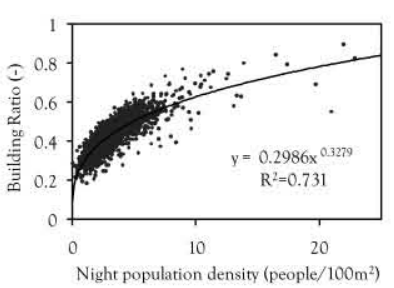

図 2 夜間人口と住居系建物 の建築面積摔の関係 (中 高層化率 0.25 以下)

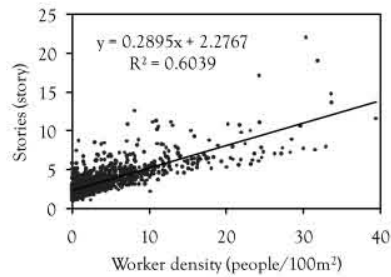

図 4 第 3 次産業従業者数密 度と商公系建物の平均 階数の関係

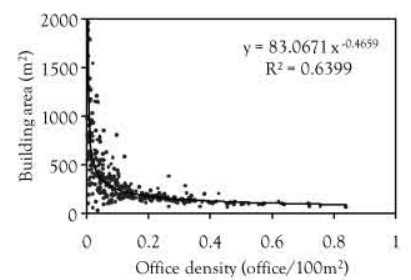

図 6 第 2 次産業事業所数密 度と工業系建物の 1 棟 当たり建築面積の関係

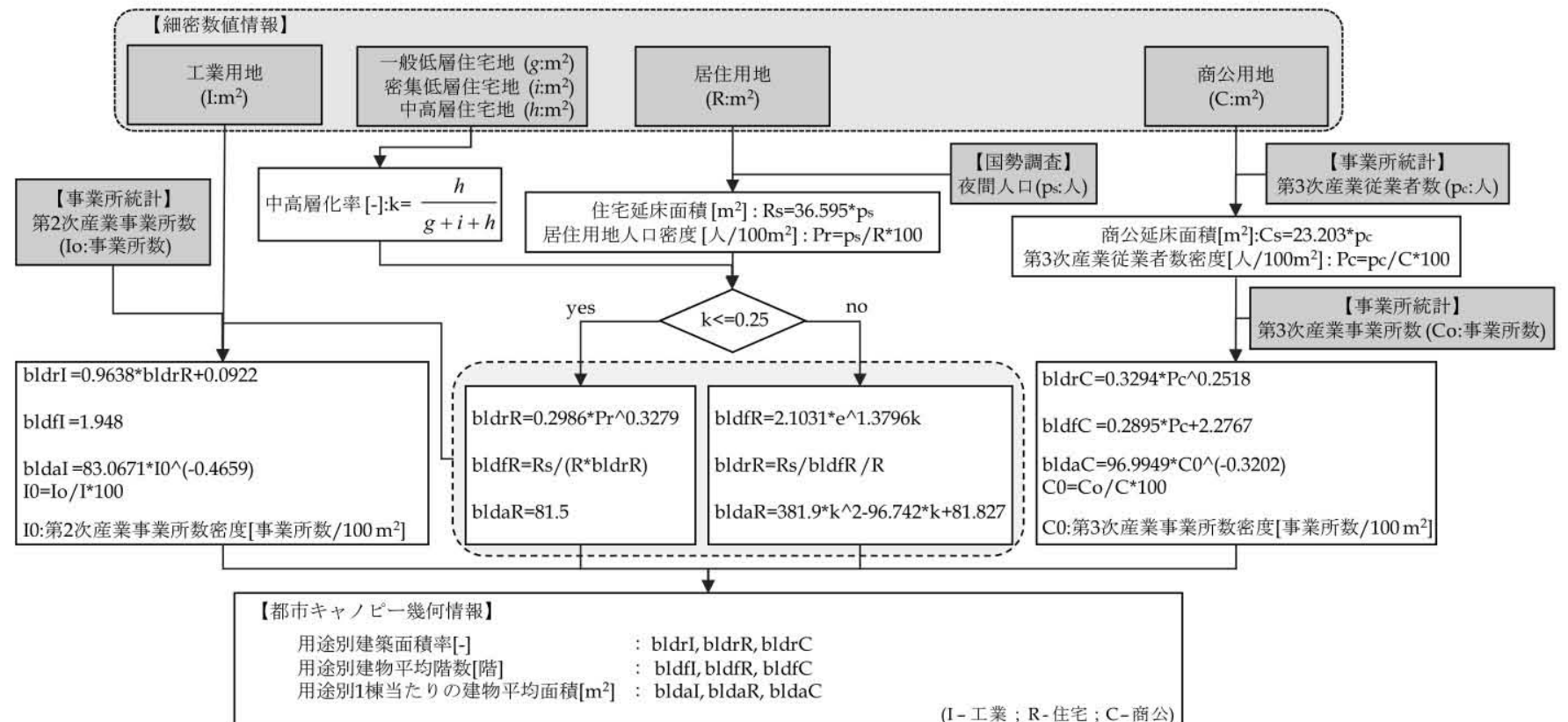

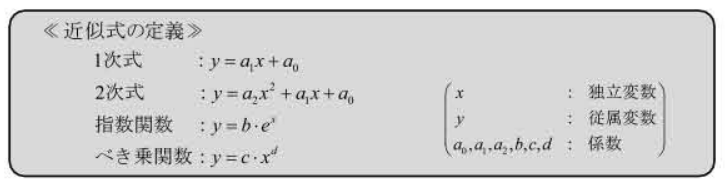

図 7 単回帰分析フロー 


\section{3-1.＼cjkstart都市キャノピー幾何情報の特徵}

東京都 GIS より集計した建物用途別の都市キャノピー幾何情 報と細密数值情報, 国勢調査及び事業所・企業統計調査のデータ の関係について以下に述べる。集計に当たり, 土地利用面積率が ゼロ，特異メッシュなどを除外した。

住居系建物については，夜間人口と住居系建物延べ床面積（図 1), 住宅地の中高層化率（中高層住宅地が居住用地全体に占める 割合）と平均階数（指数回帰, 決定係数 0.65 ), 中高層化率と 1 棟当たりの平均建築面積 (2 次式, 決定係数 0.56) の間に相関が 高かった。図 1 の近似曲線の勾配より住宅 1 人当たりの床面積は $29 \mathrm{~m}^{2}$ であり, 平成 7 年版「国民生活白書」の $30.8 \mathrm{~m}^{2}$ と概ね一致 する。戸建住宅が多い地域では夜間人口の増減は建ぺい率に直接 反映される。図 2 は中高層化率が 0.25 以下の条件で夜間人口と 建築面積率の関係を示したものである ${ }^{\text {注3) }}$

商公系建物の延べ床面積は第 3 次産業従業者数と, 平均階数は 第 3 次産業従業者数密度（第 3 次産業従業者数 / 商公用土地利用 面積）と相関が高い (図 3,4 参照)。図 3 から見積もられるオフィ スの 1 人当たり床面積約 $23 \mathrm{~m}^{2}$ は, 水鳥川 ${ }^{10)}$ による 1996 年東京 区部 1 人当たりオフィス床面積の $18.0 \mathrm{~m}^{2}$ に比べやや大きめであ る。

工業系建物の階数の頻度分布を図 5 に示す。工業系建物の平均 階数は $1.5 \sim 2.5$ 階の狭い範囲に集中していることが分かる。1 棟当たりの平均建築面積は, 第 2 次産業事業所数密度 (第 2 次産 業事業所数／工業用地土地利用面積) と図 6 に示す関係が見られ, $100 \mathrm{~m}^{2}$ 当たりの事業所数が 0.2 以上の場合では建築面積がほぼ一 定となるが，事業所数密度がこれより小さくなると鿒占状態とな り建築面積が大きくなる。工業系建物の建ぺい率は従業者数とあ まり関係なくむしろ住居系建物の建ぺい率との相関が高く，住・ 工混在地域の総体的な特徴が現われている。

\section{3-2. 単回帰分析}

3-1 の結果を踏まえ, 単回帰分析式を組み合わせて建物用途別 の都市キャノピー幾何情報を求める。単回帰の近似式は 1 次式, 2 次式, 指数関数, 及びべき乗関数とし（図 7 に近似式の定義を 記載), その中から相関が高いものを選択した。単回帰分析の全 体フローを図 7 に示す。

\section{3-3. 重回帰分析}

トレーニングデータの入力（独立変数 13 項目）と出力（従属 変数 9 項目）について重回帰分析を実施した。表 4 に標準偏回帰 係数を一覧する。

\section{3-4. ニューラルネットワーク解析}

住居系建物の場合，入力とターゲット（教師信号）は重回帰分 析の独立変数と従属变数にそれぞれ対応する。商公・工業系建物 の場合, 住宅系建物の予測結果を新たに入力側に組み入れて, 16 層の入力層を設定している。ネットワークは複数の中間層を持ち, 任意の中間層もしくは出力層のインプットとアウトプットが式 (1) に示す対数シグモイド伝達関数に従う。
表 4 都市キャノピー幾何情報に関する重回帰分析の標準偏回帰 回帰係数（記号定義同図 3）

\begin{tabular}{l|rrr|rrr|rrr}
\hline & \multicolumn{3}{|c|}{ 住居系 } & \multicolumn{3}{|c|}{ 商公系 } & \multicolumn{3}{c}{ 工業系 } \\
\cline { 2 - 10 } & bldrR & bldfR & bldaR & bldrC & bldfC & bldaC & bldrI & bldfl & bldal \\
\hline 切片 & 0.000 & 0.000 & 0.000 & 0.000 & 0.000 & 0.000 & 0.000 & 0.000 & 0.000 \\
居住用地率 & -0.252 & -0.118 & 0.081 & -0.017 & -0.273 & -0.110 & -0.214 & -0.148 & -0.250 \\
商公用地率 & -0.102 & 0.002 & 0.024 & -0.086 & 0.016 & 0.233 & -0.136 & -0.074 & -0.184 \\
工業用地率 & -0.085 & -0.053 & -0.021 & 0.084 & -0.143 & -0.031 & 0.034 & 0.084 & 0.477 \\
夜間人口 & -1.678 & -5.379 & -2.325 & -2.360 & -2.417 & -0.239 & 1.155 & -0.973 & 0.008 \\
昼間人口 & 0.500 & 0.587 & 0.139 & 0.527 & 0.439 & 0.008 & 0.280 & 0.401 & 0.075 \\
流人人口 & 1.694 & 5.334 & 2.319 & 2.238 & 2.621 & 0.202 & -1.048 & 1.016 & -0.008 \\
2 次事業所数 & 0.208 & -0.018 & -0.024 & 0.164 & -0.082 & -0.108 & 0.120 & -0.010 & -0.296 \\
2 次従業者数 & 0.039 & 0.034 & -0.012 & 0.032 & 0.115 & 0.017 & 0.052 & 0.177 & 0.075 \\
3 次事業所数 & 0.166 & -0.065 & 0.006 & 0.308 & -0.226 & -0.233 & 0.206 & 0.218 & 0.082 \\
3 次従業者数 & 0.113 & 0.153 & -0.038 & 0.242 & 0.553 & 0.128 & -0.132 & -0.151 & -0.025 \\
一般低層住宅率 & 0.733 & 0.194 & -0.267 & -0.108 & 0.041 & -0.525 & 0.305 & 0.342 & 0.051 \\
密集低層住宅率 & 0.571 & 0.168 & -0.178 & -0.026 & 0.028 & -0.360 & 0.233 & 0.272 & 0.029 \\
中高層住宅率 & 0.370 & 0.742 & 0.094 & -0.083 & 0.070 & -0.249 & 0.028 & 0.103 & 0.022 \\
\hline
\end{tabular}

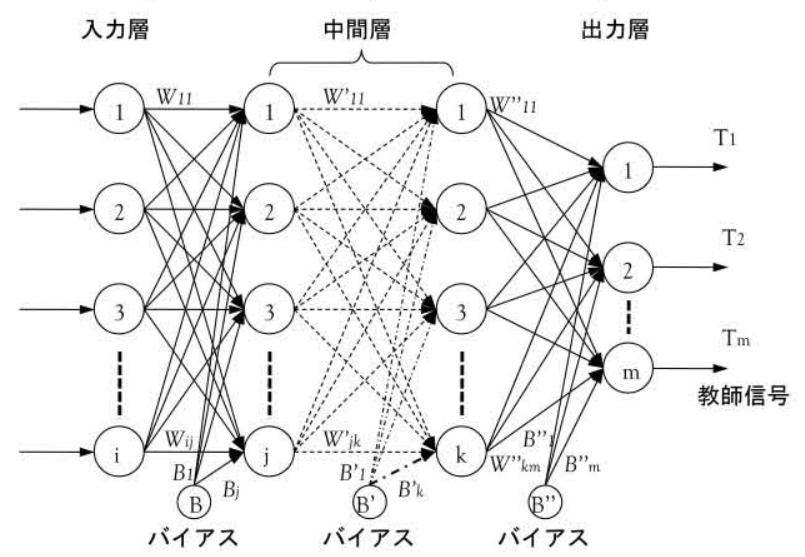

図 8 多層中間層型ニューラルネットワーク

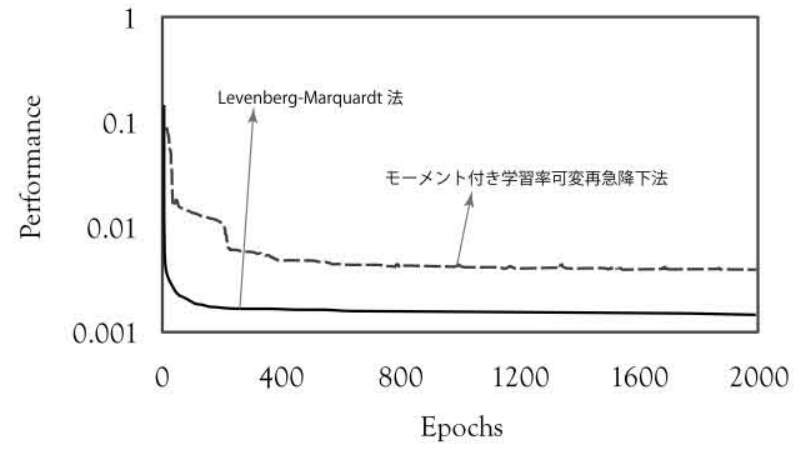

図 9 学習階数とパフォーマンスの収束状況（住居系）

\section{表 5 推定結果の比較}

\begin{tabular}{|c|c|c|c|c|c|c|c|}
\hline \multirow{2}{*}{\multicolumn{2}{|c|}{ 用途ごと幾何情報 }} & \multicolumn{2}{|c|}{ 単回帰 } & \multicolumn{2}{|c|}{ 重回帰 } & \multicolumn{2}{|c|}{ ニューラルネットワーク* } \\
\hline & & RMS & $\mathrm{R}^{2}[-]$ & RMS & $\mathrm{R}^{2}[-]$ & RMS & $\mathrm{R}^{2}[-]$ \\
\hline \multirow{3}{*}{$\begin{array}{l}\text { 售 } \\
\text { 系 }\end{array}$} & 建築面積率 [-] & 0.115 & 0.532 & 0.067 & 0.648 & 0.039 & 0.880 \\
\hline & 階数 [階] & 1.415 & 0.296 & 1.136 & 0.512 & 0.387 & 0.943 \\
\hline & 1 棟建築面積 $\left[\mathrm{m}^{2}\right]$ & 192.535 & 0.079 & 192.009 & 0.082 & 14.850 & 0.995 \\
\hline \multirow{3}{*}{$\begin{array}{l}\text { 商 } \\
\text { 采 }\end{array}$} & 建築面積率 [-] & 0.093 & 0.495 & 0.091 & 0.500 & 0.071 & 0.702 \\
\hline & 階数 [ 階] & 0.978 & 0.522 & 0.802 & 0.644 & 0.470 & 0.878 \\
\hline & 1 棟建築面積 $\left[\mathrm{m}^{2}\right]$ & 304.139 & 0.155 & 269.396 & 0.316 & 74.971 & 0.947 \\
\hline \multirow{3}{*}{$\begin{array}{l}\text { 工 } \\
\text { 業 } \\
\text { 系 }\end{array}$} & 建築面積率 $[-]$ & 0.193 & 0.195 & 0.154 & 0.371 & 0.103 & 0.719 \\
\hline & 階数 [ 階 ] & 0.769 & --- & 0.6243 & 0.272 & 0.463 & 0.622 \\
\hline & 1 棟建築面積 $\left[\mathrm{m}^{2}\right]$ & 271.747 & 0.345 & 190.324 & 0.342 & 63.296 & 0.927 \\
\hline
\end{tabular}



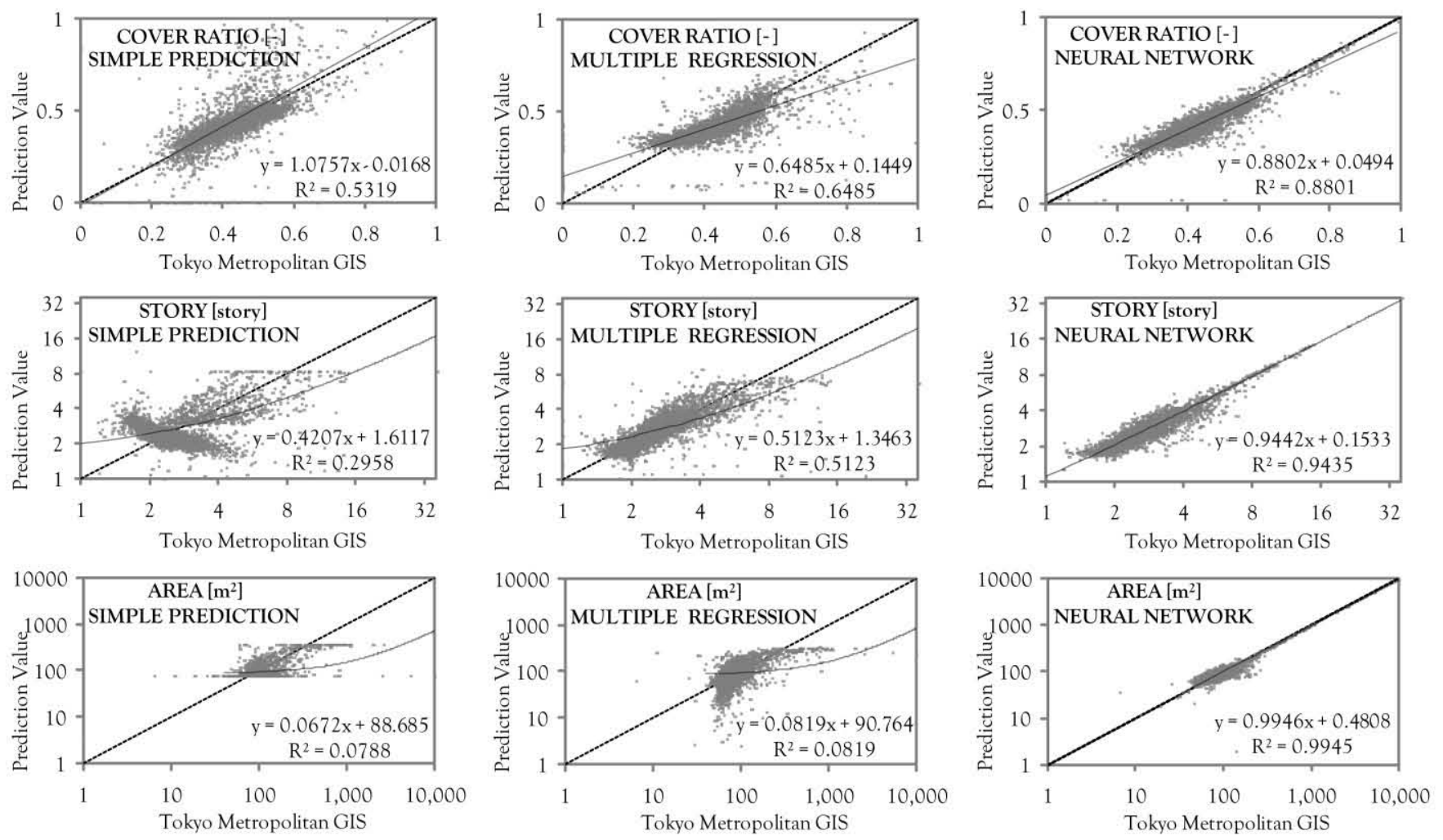

図 10 都市キャノピー幾何情報の推定結果（住居系）

ニューラルネットワークの中間層数 $: 3$, 中間層ユニット数 $: 8 \rightarrow 12 \rightarrow 8$

$$
\text { output }=\frac{1}{1+\exp \left\{-\left(\sum_{n-1}^{i} \text { input }_{n} \cdot W_{n j}+B_{j}\right)\right\}}
$$

ここで, $W_{n j}$ は $n$ 番目の入力から層の $j$ 番目のユニットへの結 合重みであり, $B_{j}$ が層の $j$ 番目のユニットのバイアスである。ネッ トワークの構造を図 8 に示す。また, 収束を高速化するために, 重みとバイアスを更新するアルゴリズムとしてレーベンバーグ・ マルカート (Levenberg-Marquardt) 法を導入した。LevenbergMarquardt 法は非線形最小 2 乗問題の解法として最も効率的な方 法の一つとされている ${ }^{11)}$ 。Jacobian 行列をJとして, LevenbergMarquardt 法の更新式を式（2）で表すことができる。

$$
\mathbf{x}_{k+1}=\mathbf{x}_{k}-\left[\mathbf{J}^{T} \mathbf{J}+\mu \mathbf{I}\right]^{-1} \mathbf{J}^{T} \mathbf{e}
$$

I， $\mu$, e がそれぞれ単位行列，スカラー量及び誤差ベクトルを 意味する。Levenberg-Marquardt 法の導入によって安定誤差をモー メント付き学習率可変最急降下法の半分以下に下げることができ た。図 9 に両手法による学習回数 2000 回までのパフォーマンス を示す。

ニューラルネットワークでは中間層数及び中間層に含まれるユ ニットの数がネットワークの推定精度, すなわち汎化能力に大き く寄与するが, それらを決める一般的な方法は確立されていない。 そこで, 本研究では中間層数を $1 \sim 5$, ユニット数を $4 \sim 24$ の 間で変化させ，ネットワーク構造を試行錯誤で決定する。その結 果, 全データ（3903 個のターゲット）を学習データに使用した
場合, 中間層数 4 (各層のユニット数 $16,20,24,20$ ) のネット ワークがターゲットに対する出力䛊差を最小にした。しかし，全 データから部分的に学習データを抽出し, 全データをニューラル 解析した場合, 中間層数 3 (各層のユニット数 $8,12,8)$ のネッ トワークが今回の組み合わせの中で最も優れていることが分かっ た。ここで, 学習データの抽出は乱数処理で実施し, 全データ数 に対する学習データ数の割合が $20 \%, 50 \%, 70 \%$ の 3 段階とした。 汎化能力を考慮し, 以降は中間層数 3 (各層のユニット数 8,12 , 8）の結果について述べる。

学習回数の設定については,住宅系を対象に 100000 回まで のテスト学習を実施し, パフォーマンスが 2000 回学習時と $5 \%$ しか違わないため, 学習回数は 2000 回とした。LevenbergMarquardt 法においては, スカラー量 $\mu$ の初期值を 0.001 , ステッ プごとの $\mu$ の係数を 10 (増加時) と 0.1 (減少時)に設定している。 なお，ネットワークの重みの初期值は 50 としている。

\section{3-5. 推定結果の比較}

全データ（3903 メッシュ）を使用した場合における建物用途 ごとの都市キャノピー幾何情報の推定精度を表 5 に一覧する。単 回帰分析では商公系建物の階数, 住居及び商公系建物の建築面積 率においては 0.5 前後の決定係数を示したが, その他の項目では 決定係数が低い。重回帰分析による推定結果は概ね単回帰予測よ り良い。しかし，1棟当たりの平均建築面積の推定精度は全体的 に低く,特に住居系建物の決定係数はわずか 0.082 であった。一方, ニューラルネットワークはすべての項目において良好な推定精度 
が得られた。

図 10 は, 住宅系建物の建築面積率 (cover ratio), メッシュ平 均階数（story）及び 1 棟当たりのメッシュ平均建築面積（area） における単回帰分析 (simple prediction), 重回帰分析 (multiple regression), ニューラルネットワーク (neural network) の 3 手法 による推定値と GIS 集計值の相関を示している。ニューラルネッ トワークは単回帰及び重回帰分析では扱えない複雑な関係を持つ 項目についても高精度でターゲットを予測している。

\section{4. 都市 GIS データが整備されていない地域への適用について}

都市キャノピーモデルを用いて広範な領域を解析する場合, 都 市 GIS データが整備されていない地域を含むことから, 解析作 業に大きく支障をもたらす。そこで, 都市 GIS データが整備さ れていない地域におけるニューラルネットワークによる都市キャ ノピー幾何情報推定手法の適用について検討する。

便宜的に東京 23 区を都市 GIS データの整備地域, 多摩地域を 都市 GIS データの未整備地域と見なす。そして, 東京 23 区のみ のトレーニングデータをニューラルネットワークに学習させ, 習 得したネットワークを用いて多摩地域の都市キャノピー幾何情報 を推定する。合わせて, ニューラルネットワークの汎用性を評価 するため, 重回帰分析を実施し, 両者の結果を比較しながら考察 を行う。

東京 23 区の都市構造は他の地域と異なることが予想され, 統 計的に地区の相違をニューラルネットワークに反映する必要があ る。そこで, マハラノビス (Mahalanobis) 距離を活用し, 両地 区の統計的な類似度を判定した。未知ベクトル $\mathbf{x}$ が平均ベクトル $\mathbf{u}$ を持つ群に対するマハラノビス距離 $\left(D_{M}\right)$ は次式で表される。

$$
D_{M}(\mathbf{x}, \mathbf{u})=(\mathbf{x}-\mathbf{u})^{T} \sum^{-1}(\mathbf{x}-\mathbf{u})
$$

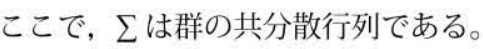

本研究が解析対象とする 3903 メッシュの中に, 東京 23 区に 属するメッシュは 2601 個存在し, 多摩地域に属するメッシュは 残り 1842 個である。ニューラルネットワークのトレーニングデー タの入力 13 項目について東京 23 区の統計分析を行い, 多摩地 域のメッシュデータを適用するとマハラノビス距離は 1.157 から 307.077 の数值を示した。多摩地域のメッシュの内, マハラノビ ス距離が 20 以下のメッシュは全体の約 $90 \%$ を占める。

マハラノビス距離とニューラルネットワークによる推定精度 の関係を重回帰分析による結果と合わせて図 11 と図 12 に示す。 マハラノビス距離が 15 以下においては, 住居系建物の建築面積 率, 1 棟建築面積ともにニューラルネットワークの RMS 誤差は そのほとんどが重回帰分析と比べ值が小さいことが分かる。特に 5 以下では, 東京都 GIS 全データを用いた表 5 の分析結果と遜色 ない精度で予測できている。しかし, マハラノビス距離が 15 以 上になると, ニューラルネットワークの誤差が急増し, 両者の 関係は逆転する。したがって, ニューラルネットワークで他地

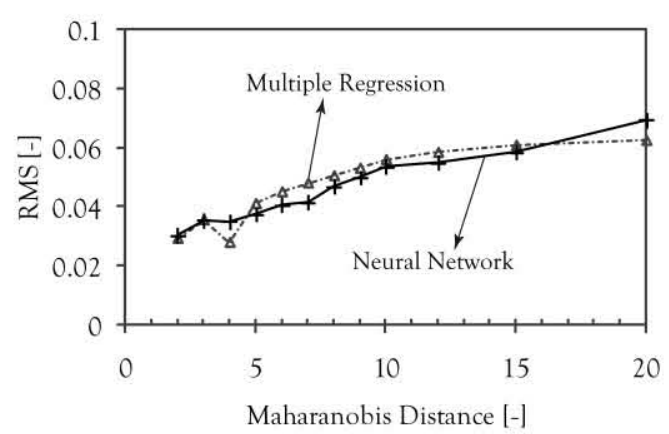

図 11 マハラノビス距離と推定精度 (住居系, 建築面積率)

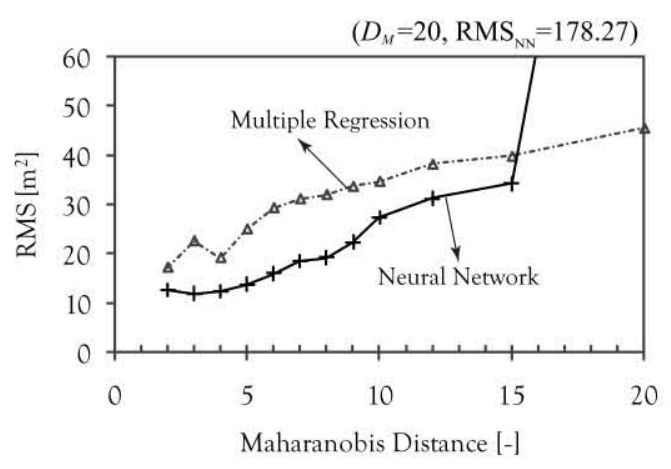

図 12 マハラノビス距離と推定精度（住居系，1 棟建築面積）

域の解析を行う場合, マハラノビス距離などで類似の地区を選定 することが望ましい。

\section{5. まとめ}

本研究では一般的に入手が容易な細密数值情報及び国勢調査, 事業所・企業統計調査資料を用いて都市キャノピー幾何情報を推 定する手法について検討を行った。得られた知見を以下に示す。

（1）細密数值情報から土地利用面積率を推定する方法として単 回帰, 重回帰, ニューラルネットワークを考え, いずれも良好な 推定精度を得た。ただし, 単回帰の場合, 道路面積が他用途へ読 み替えられる誤差の補正が必要である。

（2）都市キャノピー幾何情報の推定精度は, 単回帰分析, 重回 帰分析, ニューラルネットワークの順に良くなる。ニューラルネッ トワークの場合はすべてのケースにおいて決定係数が 0.6 以上と なり良好な結果が得られた。

（3）東京 23 区をトレーニングデータとして, 他の地域へニュー ラルネットワークの適用可能性を検討し, マハラノビス距離など で類似の地区を選定することが望ましいことを指摘した。

\section{謝辞}

環境省が設置した「ヒートアイランド現象の実態把握及び対策 評価手法に関する調査委員会」（尾島俊雄委員長）から各種デー タを提供していただいた。また，本研究は住友財団の助成をいた だいた。ここに記して感謝の意を表したい。 


\section{注}

注 1) MATLAB のバージョンR2007b, Neural Network Toolbox バージョン 5.1 を使用した。

注 2）二ューラルネットワークによる土地利用面積率の推定に扔いては, 入力 層, 中間層（層数 2 , 各層のユニット数 4,6 ), 出力層の 4 層から成るネッ トワークを採用し, 学習率 0.01 , モーメント係数 0.9 , 学習回数 2000 回 の設定を行った。

注 3） データ集計の結果, 居住系建物の平均階数が 3 階以下となる地域では, 中高層化率が 0.25 以下になるケースが多いことが分かった。

\section{参考文献}

1）石井 陽，鹿島 茂：都市構造が交通エネルギー消費量に与える影響の 分析，環境情報科学論文集，第 21 号， pp. $619 \sim 624 ， 2007$

2）宮崎ひろ志, 森山正和: 阪神・淡路大震災における地震火災規模と緑被率, 建ぺい率等市街地特性との相関解析, 日本建築学会計画系論文集, 第 520 号, pp. $77 \sim 81, \quad 1999.6$

3）伊藤 篤, 近江 隆, 石坂公一: 機会犯罪の成立に関連する都市空間特性 に関する研究 放火犯罪を対象にして, 第 34 回日本都市計画学会学術 研究論文集, 第 34 号, pp. $721 \sim 726,1999$

4）森泉孝信, 河合 徹, 稲垣厚至, 神田学: 屋外都市模型による建物高さ の非一様性が大気に及ぼす影響の㛟討, 水工学論文集, 第 52 巻, 2008 . 2

（2008年 3 月 10 日原稿受理，2008年 8 月20日採用決定） 